\title{
A Comparative Study of Durability of Solid Oxide Electrolysis Cells Tested for Co- Electrolysis under Galvanostatic and Potentiostatic Conditions
}

Rao, Megha; Sun, Xiufu; Hagen, Anke

Published in:

Journal of the Electrochemical Society

Link to article, DOI:

10.1149/2.0151810jes

Publication date:

2018

Document Version

Publisher's PDF, also known as Version of record

Link back to DTU Orbit

Citation (APA):

Rao, M., Sun, X., \& Hagen, A. (2018). A Comparative Study of Durability of Solid Oxide Electrolysis Cells Tested for Co-Electrolysis under Galvanostatic and Potentiostatic Conditions. Journal of the Electrochemical Society, 165(10), F748-F755. https://doi.org/10.1149/2.0151810jes

\section{General rights}

Copyright and moral rights for the publications made accessible in the public portal are retained by the authors and/or other copyright owners and it is a condition of accessing publications that users recognise and abide by the legal requirements associated with these rights.

- Users may download and print one copy of any publication from the public portal for the purpose of private study or research.

- You may not further distribute the material or use it for any profit-making activity or commercial gain

- You may freely distribute the URL identifying the publication in the public portal 


\title{
A Comparative Study of Durability of Solid Oxide Electrolysis Cells Tested for Co-Electrolysis under Galvanostatic and Potentiostatic Conditions
}

\author{
M. Rao, $\oplus^{z}$ X. Sun, and A. Hagen \\ Department of Energy Conversion and Storage, Technical University of Denmark, Roskilde 4000, Denmark
}

\begin{abstract}
State-of-the-art SOECs consisting of a nickel-yttria stabilized zirconia (Ni-YSZ) fuel electrode, YSZ electrolyte and lanthanum strontium cobaltite ferrite-gadolinium doped ceria (LSCF-GDC) composite oxygen electrode were tested under co-electrolysis $\left(\mathrm{H}_{2} \mathrm{O}+\mathrm{CO}_{2}\right)$ conditions. The aim in this study was to compare the SOEC durability under co-electrolysis conditions between galvanostatic and potentiostatic modes. Specifically, the cells were operated at $0.75 \mathrm{~A} / \mathrm{cm}^{2}$ (galvanostatic) and at $1.2 \mathrm{~V}$ (potentiostatic) at $750^{\circ} \mathrm{C}$ for over 1000 hours. In both modes, a larger degradation was observed initially for the first 200 hours of testing, followed by a more stable performance over longer operating times. Interestingly, there was a difference in trends of serial and polarization resistances' evolution. In galvanostatic mode of operation, both increased while for potentiostatic mode only the polarization resistance increased over time. The difference of the degradation was attributed to the overpotentials being experienced by the cells in the respective modes. Trends of the area specific resistance (ASR) and detailed electrochemical analysis of the performance of the cell under durability conditions for both modes indicated that the degradation was due to both the fuel electrode and the oxygen electrode, with an additional contribution from fuel electrode in galvanostatic testing. Microstructural analysis also confirmed the degradation of the active fuel electrode.

(C) The Author(s) 2018. Published by ECS. This is an open access article distributed under the terms of the Creative Commons Attribution Non-Commercial No Derivatives 4.0 License (CC BY-NC-ND, http://creativecommons.org/licenses/by-nc-nd/4.0/), which permits non-commercial reuse, distribution, and reproduction in any medium, provided the original work is not changed in any way and is properly cited. For permission for commercial reuse, please email: oa@electrochem.org. [DOI: 10.1149/2.0151810jes]
\end{abstract}

(cc) BY-NC-ND

Manuscript submitted April 12, 2018; revised manuscript received June 11, 2018. Published June 30, 2018. This was Paper 1717 presented at the National Harbor, Maryland Meeting of the Society, October 1-5, 2017.

For the past few decades, the use of renewable energy sources for power production has been increasing. Europe aims at producing most of its electricity through renewable energy sources by 2050 , lowering greenhouse gas emissions significantly as a consequence. ${ }^{1}$ Solar and wind energy have already acquired the status of matured technologies for renewable electricity production..$^{2-4}$ The larger shares of electricity from these fluctuating sources require efficient electricity storage technologies. Some of the examples of such available storage technologies are compressed air, batteries and flywheels. ${ }^{3}$ In this context, fuel cells and electrolysis cells become interesting for both, energy production and storage. Especially, high temperature electrolysis using solid oxide electrolysis cells (SOECs) has gained significant interest, owing to the capability to convert $\mathrm{CO}_{2}$ and $\mathrm{H}_{2} \mathrm{O}$ together to produce syngas $\left(\mathrm{CO}+\mathrm{H}_{2}\right){ }^{2,4-6}$ Power-to-Gas $(\mathrm{PtG})$ and Power-to-liquid (PtL) scenarios have gained significant attention in the past few decades. In case of renewable energy production, intermittent energy can be stored in the form of gas or liquids through fuel production from syngas. ${ }^{2,6-8}$

The motivation of using SOECs in the context of PtL and PtG solutions is due to its high electrical efficiency, up to $100 \%$. To perform electrolysis operation, the required energy is provided partly by the high temperature operation of SOEC and the remainder is provided by electricity. ${ }^{5,9}$ While operating SOEC in co-electrolysis mode, syngas is produced which can be further converted downstream into various fuels which can be used for energy storage, transportation, heating etc. ${ }^{4,6,7}$ In the context of PtG technology, production of methane is of particular interest due to the existing extensive infrastructure for storage and distribution. ${ }^{2,4,6,8}$ An interesting aspect of co-electrolysis operation using SOEC is internal methane formation at high pressure. ${ }^{10}$ However, limited studies have been carried out in this field. ${ }^{11}$

Aiming at 5-10 years of operation, durability of SOECs is still one of the major challenges. Durability testing of SOEC cells have previously been reported both for steam and co-electrolysis conditions. ${ }^{12-15}$ The cells have been tested for thousands of hours under different testing conditions such as temperature, gas composition and applied current. ${ }^{12-18}$ From a system point of view, it is desirable to operate SOEC at thermoneutral voltage, i.e. the voltage where no additional heat is required for the electrolysis reaction. However, due to the technical ease of galvanostatic operation and data analysis, most tests have

${ }^{\text {z} E-m a i l: ~ m r a o @ d t u . d k ~}$ been carried out in this mode. ${ }^{19}$ Studies of degradation mechanisms under potentiostatic operating conditions are rare. ${ }^{20}$ Comparison of the durability and degradation mechanisms between galvanostatic and potentiostatic operation has not been widely reported in literature.

In this work, SOEC cells consisting of Ni-YSZ fuel electrode support, Ni-YSZ fuel electrode, YSZ electrolyte, CGO barrier layer and LSCF-CGO oxygen electrode were tested for ca. 1000 hours for durability under co-electrolysis conditions in galvanostatic and potentiostatic modes. Post-test SEM analysis was carried out to analyze the microstructural changes after long-term testing. Both electrochemical and microstructural analyses were used to identify the detailed degradation mechanisms in both modes.

\section{Experimental}

Three SOECs from HTceramix consisting of a Nickel-Yttria Stabilized Zirconia (Ni-YSZ) fuel electrode with a thickness of 220-260 $\mu \mathrm{m}$, a 6-10 $\mu \mathrm{m}$ thick YSZ electrolyte, a CGO inter-diffusion barrier layer and a 40-60 $\mu \mathrm{m}$ thick composite oxygen electrode of lanthanum strontium cobaltite ferrite-gadolinium doped ceria (LSCFCGO) were tested. The active area of the cells was $16 \mathrm{~cm}^{2}$.

The cells were tested in a setup as described in Refs. 21,22. They were mounted in an alumina cell test house with gold and nickel as current collector contact components on the oxygen and fuel side, respectively. A gold sealing was used on the fuel side. 4 kilograms of weight was applied on top of the cell house during start up to ensure gastight sealants and electrical contact between the cell and the contact components. The cells were heated to $800^{\circ} \mathrm{C}$, at a ramp rate of $60^{\circ} \mathrm{C} / \mathrm{h}$, and held for 2 hours prior to reduction. During heating, $\mathrm{N}_{2}$ and air were supplied to the fuel electrode and oxygen electrode compartment, respectively. The cells were reduced with $\mathrm{N}_{2}$ and $\mathrm{H}_{2}$ beginning from $90 \% \mathrm{~N}_{2}$ for 1 hour, eventually shifting the flow to pure $\mathrm{H}_{2}$ for 1 hour on the fuel electrode. On the oxygen electrode, a constant air flow was maintained. Initial electrochemical characterization of the cell was performed afterwards.

Three cells were tested, named Cell A, Cell B and Cell C. Cell A only experienced reduction and an initial electrochemical characterization (fingerprint), while Cell B was tested galvanostatically and Cell C was tested potentiostatically for ca. 1000 hours. The fingerprint is an electrochemical characterization of the cells at $800^{\circ} \mathrm{C}, 750^{\circ} \mathrm{C}$, 
$700^{\circ} \mathrm{C}$ and $650^{\circ} \mathrm{C}$. At each temperature, i-V characterization and EIS measurements were performed with either air or $\mathrm{O}_{2}$ supplied to the oxygen electrode. The steam content was varied as $4 \%, 20 \%, 50 \%$, $80 \%$ and $90 \%$ with $\mathrm{H}_{2}$ on the fuel electrode. Furthermore, characterization in co-electrolysis gas mixture was carried out with $40 \%$ $\mathrm{H}_{2} \mathrm{O}+50 \% \mathrm{CO}_{2}+10 \% \mathrm{H}_{2}, 45 \% \mathrm{H}_{2} \mathrm{O}+45 \% \mathrm{CO}_{2}+10 \% \mathrm{H}_{2}$ and $65 \%$ $\mathrm{H}_{2} \mathrm{O}+25 \% \mathrm{CO}_{2}+10 \% \mathrm{H}_{2}$ supplied to the fuel electrode compartment. EIS measurements during fingerprint were carried out at zero DC current using a Solartron 1255 frequency analyzer and an external shunt resistor in series with the cell. The spectra were recorded from 96850 to $0.08 \mathrm{~Hz}$ with 12 points per decade and were corrected using the short circuit impedance response of the test setup. A short-circuit impedance response for compensation of EIS was measured without the cell test house. i.e. by short circuiting the current and voltage wires outside of the furnace. Therefore the inductance here was mainly due to current leads on the cell test house inside the furnace, which is not identical in all the tests. From the impedance spectra, the ohmic resistance (serial resistance, Rs) was taken as the value of the real part of the impedance at $96850 \mathrm{~Hz}$. Typically the Rs is obtained from the intercept of the Z'-axis, however, as previously reported by Sun et al., ${ }^{15}$ the calculation of Rs as done in this work provides a more correct value. The difference between the intercept and this value is very small. The polarization resistance ( $\mathrm{Rp})$ was then calculated as the difference in the real part of the impedance at $96850 \mathrm{~Hz}$ and $0.08 \mathrm{~Hz}$. EIS measurements during durability tests were carried out at $0.75 \mathrm{~A} / \mathrm{cm}^{2}$ for galvanostatic operation and at $1.2 \mathrm{~V}$ during potentiostatic operation with a frequency range of $96850 \mathrm{kHz}$ to $0.08 \mathrm{~Hz}$. i-V curves were recorded both in fuel cell (FC) and electrolysis (EC) mode and as function of the gas composition. For FC mode, the minimum voltage limit was set to $650 \mathrm{mV}$ while for $\mathrm{EC}$ mode the curve maximum voltage was set to $1350 \mathrm{mV}$. The $\mathrm{i}-\mathrm{V}$ curves were recorded in 3 parts with step sizes of firstly $0.25 \mathrm{~A}$, followed by $0.5 \mathrm{~A}$ in the linear region and finally $0.25 \mathrm{~A}$. The step size of $0.25 \mathrm{~A}$ was maintained until either the current or voltage threshold was reached.

The electrochemical durability testing of the cells was carried out in co-electrolysis mode with $65 \% \mathrm{H}_{2} \mathrm{O}+25 \% \mathrm{CO}_{2}+10 \% \mathrm{H}_{2}$ in the fuel feed corresponding to $23 \% \mathrm{CO}_{2}+2 \% \mathrm{CO}+8 \% \mathrm{H}_{2}+67 \%$ $\mathrm{H}_{2} \mathrm{O}$ equilibrium composition. Cell $\mathrm{B}$ was tested galvanostatically at $0.75 \mathrm{~A} / \mathrm{cm}^{2}$ and $750^{\circ} \mathrm{C}$. The fuel utilization was fixed at $48.7 \%$ for galvanostatic operation. Cell $\mathrm{C}$ was operated under the similar and constant gas composition, potentiostatically at $1.2 \mathrm{~V}$ and $750^{\circ} \mathrm{C}$. The reactant utilization changed with the current during operation, starting from $38.5 \%$ and ending at $20.6 \%$. Analysis of the impedance data was performed using the software Ravdav. ${ }^{23}$

Post-test analysis of the cells was performed using scanning electron microscopy (SEM). Polished cross-sections along the hydrogen/steam flow path from inlet to outlet were prepared for all cells. The cell microstructure was examined using a Supra-35 scanning electron microscope equipped with a field emission gun (FE-SEM, Carl Zeiss) and an energy-dispersive X-ray spectrometer (EDS, Thermo Electron Corporation). For SEM imaging, low voltage (LV) SEM through an Inlens detector and an accelerating voltage of $1 \mathrm{keV}$ was employed. ${ }^{24}$ The samples were embedded in epoxy and carbon coated to avoid charging of the sample surface and to ensure a grounded connection. Fractured samples were prepared from hydrogen inlet to outlet and were carbon coated for analysis. In-lens and SE detectors were used at $5 \mathrm{keV}$ to investigate the surface morphology of these samples.

\section{Results and Discussion}

Three SoA cells were characterized and the initial performance under the conditions for co-electrolysis i.e., $65 \%$ $\mathrm{H}_{2} \mathrm{O}+25 \% \mathrm{CO}_{2}+10 \% \mathrm{H}_{2}$ at fuel electrode with oxygen at the oxygen electrode at $750^{\circ} \mathrm{C}$ are compared in Figure 1. It was of interest to test cells at nominal temperature given by the supplier as well as aimed at by the project (EU-Eco). The OCV values are very similar to each other as well as to the theoretical value, indicating a tight setup. Cell-C deviates from the other cells at higher current densities, and

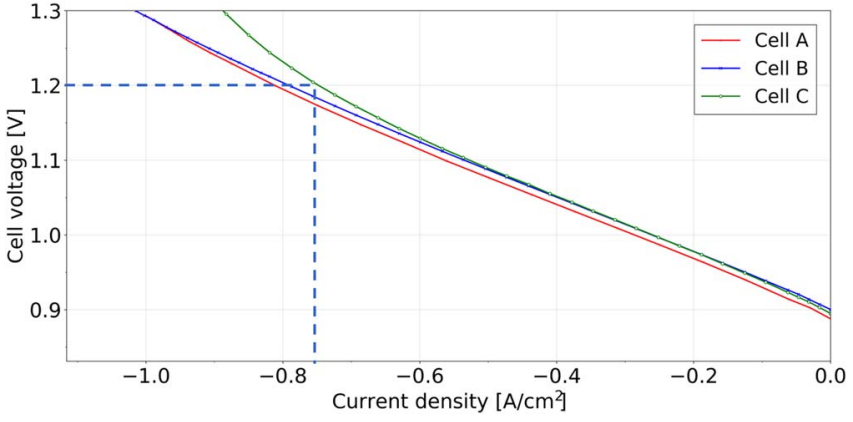

Figure 1. Initial i-V curves of cells $\mathrm{A}, \mathrm{B}$, and $\mathrm{C}$ at $750^{\circ} \mathrm{C}$ with $65 \% \mathrm{H}_{2} \mathrm{O}+25 \% \mathrm{CO}_{2}+10 \% \mathrm{H}_{2}$ supplied to the fuel electrode compartment and $\mathrm{O}_{2}$ supplied to the oxygen electrode compartment (Selection of operation point for durability testing is marked with broken lines).

hence the operating point for long-term operation was chosen within the window where the cells exhibited more similar behavior.

It is particularly of interest to operate the cell in potentiostatic mode and it is desirable to operate the cell at thermoneutral voltage (1.33 $\mathrm{V}$ for the given gas composition). However, for the cells in this study, such an operating voltage would yield high current densities of approximately $1 \mathrm{~A} / \mathrm{cm}^{2}$ (See Figure 1), which may result in significant degradation. ${ }^{13}$ From the $\mathrm{i}-\mathrm{V}$ curves shown in Figure 1, similar performance can be assumed while operating at $0.75 \mathrm{~A} / \mathrm{cm}^{2}$ for cells $\mathrm{A}$ and $\mathrm{B}$, which corresponds to $1.2 \mathrm{~V}$ for Cell $\mathrm{C}$. This operating voltage was therefore chosen for the potentiostatic test and the corresponding current density for the galvanostatic test. Cell A was used as reference for the micro structural analysis (see Figure 11).

\section{Electrochemical Analysis}

Cell-B was tested galvanostatically at $0.75 \mathrm{~A} / \mathrm{cm}^{2}$ for 1055 hours. The evolution of cell voltage and current density can be seen in Figure 2a. The increase of cell voltage was fast in the initial 200 hours of operation with a degradation rate of $0.7 \mathrm{mV} / \mathrm{h}(58 \% / 1000 \mathrm{~h})$. Later on, during the durability test, there was a slower increase of the cell voltage. In the last 855 hours of operation, the degradation rate was $0.13 \mathrm{mV} / \mathrm{h}(10 \% / 1000 \mathrm{~h})$.

Cell $\mathrm{C}$ was tested potentiostatically at $1.2 \mathrm{~V}$ for 1005 hours and the evolution of the cell voltage and current density over the testing period can be seen in Figure 2b. Here, the initial current density at the start of durability test was lower than that of Cell B (see double headed arrow on Figure 2b). The polarization resistance of Cell $\mathrm{C}$ (potentiostatic test) was larger than in the case of Cell B (galvanostatic test) when the durability test was started (Figure 6), although the initial values should have been similar when looking at the first iV curves (Figure 1) that were the basis for the selection of operating current and voltage in these two tests. Obviously, Cell $\mathrm{C}$ had already experienced some degradation between this first $\mathrm{iV}$ curve and the starting of the durability test with the starting Rp almost double of the Cell B. Like in the case of galvanostatic testing, a rapid decrease of the current density was observed in the initial $200 \mathrm{~h}$ of testing which corresponds to a degradation rate of $17.2 \mathrm{~mA} / \mathrm{h}(181 \% / 1000 \mathrm{~h})$. The decrease of current for the remainder of the test was much smaller, with a cell degradation rate of $1.3 \mathrm{~mA} / \mathrm{h}(14 \% / 1000 \mathrm{~h})$ during the last $805 \mathrm{~h}$ of operation. In the initial 200 hours of durability testing, the cells degrade faster and the degradation rates typically decrease with increasing operation times. This behavior has been observed on different types of state-of-the-art cells. ${ }^{14}$

Typically, degradation rates are given in change of cell voltage per $1000 \mathrm{~h}$. Under potentiostatic conditions, the changing parameter is the current density and the degradation rate was therefore calculated as change of this parameter. However, these two parameters cannot be compared directly. To make a better comparison of the cell degradation in both modes of operation, area specific resistances (ASR) were 

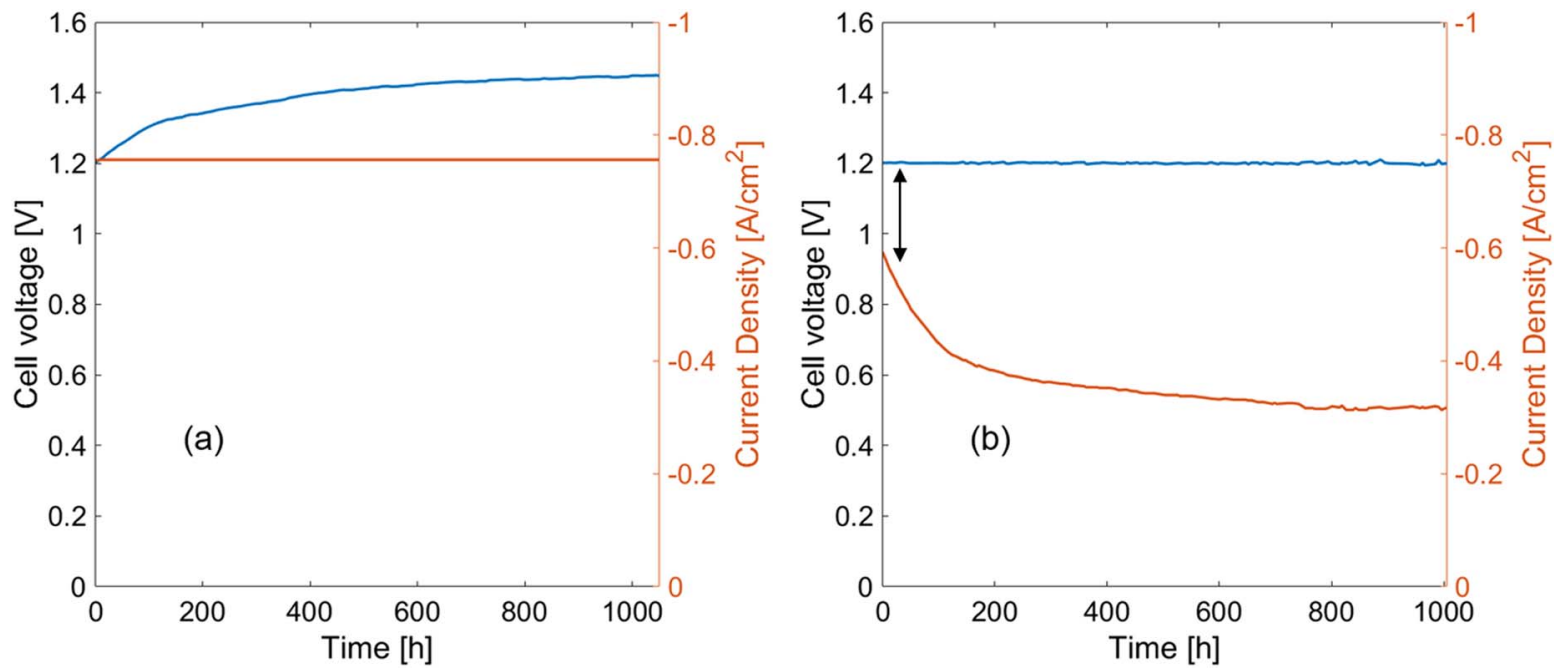

Figure 2. Current density and cell voltage evolution as function of time during the (a) galvanostatic operation of Cell B, (b) potentiostatic testing of Cell C with $65 \% \mathrm{H}_{2} \mathrm{O}+25 \% \mathrm{CO}_{2}+10 \% \mathrm{H}_{2}$ supplied to the fuel electrode compartment and $\mathrm{O}_{2}$ supplied to the oxygen electrode at $750^{\circ} \mathrm{C}$.

calculated using the following equation:

$$
A S R=(\mathrm{OCV}-U) / I
$$

where, $O C V$ is the open circuit voltage determined through the Nernst equation, $U$ is the cell voltage, and $I$ is the current density.

The OCV value obtained just before starting the durability testing was used for ASR calculations. The OCV before and after the test were recorded as having the same values, for each cell, thus justifying using the initial OCV for ASR calculations. In Figure 3, the ASR values as calculated according to Equation 1 are plotted as a function of time, for both galvanostatic and potentiostatic test. From the slope of the ASR curves, it is evident that the cells degrade at a significantly higher rate during the first $200 \mathrm{~h}$ (right axis in Figure 3) of operation, as mentioned earlier in this work. After the initial 200 hours, the ASR increases with a slower rate until it becomes more stable. The ASR value increased with around $9 \% / 1000 \mathrm{~h}$ for cell $\mathrm{B}$ tested under galvanostatic mode and around $14 \% / 1000 \mathrm{~h}$ for cell $\mathrm{C}$ tested under potentiostatic mode during

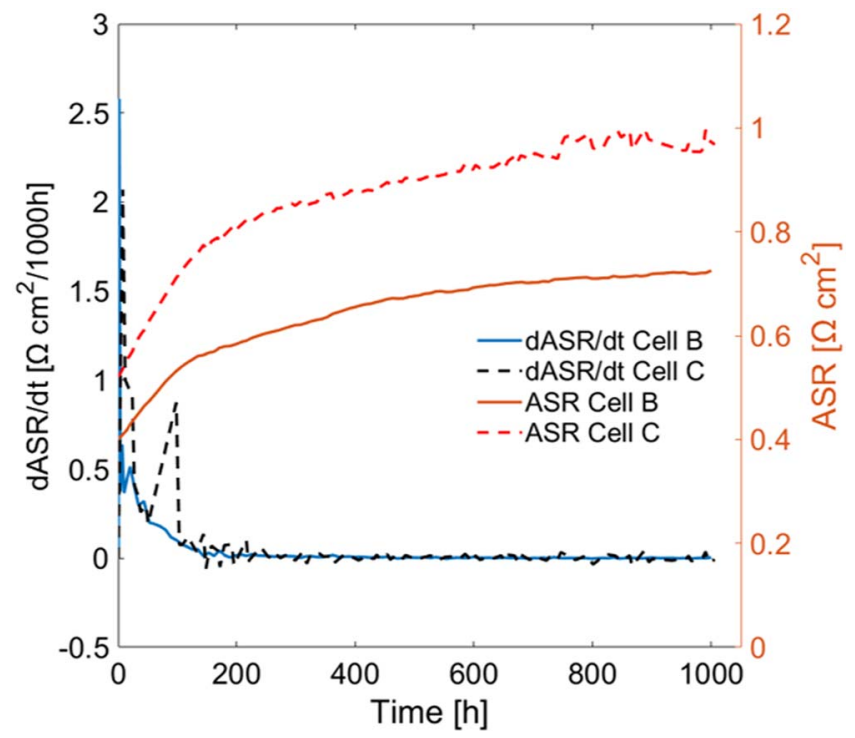

Figure 3. ASR and rate of change of ASR as a function of time (dASR/dt), with $65 \% \mathrm{H}_{2} \mathrm{O}+25 \% \mathrm{CO}_{2}+10 \% \mathrm{H}_{2}$ supplied to the fuel electrode compartment and $\mathrm{O}_{2}$ supplied to the oxygen electrode compartment at $750^{\circ} \mathrm{C}$, Cell B: $\mathrm{i}=0.75 \mathrm{~A} / \mathrm{cm}^{2}$, Cell C: $\mathrm{V}=1.2 \mathrm{~V}$. the first 200 hours. For the remainder of the testing time, the ASR evolution is similar in both modes, approximately $2 \% / 1000 \mathrm{~h}$. Thus, the observed trend for ASR degradation confirms the observations from following the cell voltage in galvanostatic mode and the current density in potentiostatic mode over time (see Figure 2). It allows though for a better direct comparison of the two operating modes, which under the applied conditions lead to similar overall degradation rates.

EIS were recorded under operation to achieve a more detailed understanding of the degradation processes within the SOEC. In Figure 4, Nyquist plots for Cell B under galvanostatic testing at 0.75 $\mathrm{A} / \mathrm{cm}^{2}$ are shown for selected operating times. It can be clearly seen that in the first 200 hours of operation the serial resistance (Rs) remained constant while $\mathrm{Rp}$ increased rapidly (twice as initial, compare also to Figure 6). During the remainder of the durability test, both Rs and Rp increased. In the last 200 hours, however, the increase of ASR of the whole cell is marginal and the cell seems to stabilize. In case of galvanostatic testing, gas conversion remained the same due to constant current density.

In Figure 5, similar plots for the cell impedance during the test at $1200 \mathrm{mV}$ are plotted for Cell C. It is interesting to note that Rs remained constant over the whole testing period. Like in the case of galvanostatic testing, the increase of Rp was higher in the initial 200 hours. Rp doubled in the first 200 hours, as seen from Figure 5. In the last 200 hours, the polarization resistance increased only slightly suggesting a stabilization of the cell performance.

In order to get a more detailed information about the degradation mechanisms, the trends of serial (Rs) and polarization $(\mathrm{Rp})$ resistances for the cells tested galvanostatically and potentiostatically were calculated from EIS under operation (see Figure 4). It should be noted that the polarization resistance for Cell $\mathrm{C}$ was significantly higher than that of Cell B at the start of durability test although initial values were similar as obtained from Figure 1. Cell $\mathrm{C}$ had already experienced certain degradation between this first iV curve (see Figure 1) and the starting of the durability test with the starting Rp almost double of the Cell B. In addition, cell-to-cell variation can be one of the reasons for the difference in polarization resistance. As indicated by broken lines in Figure 6, the behavior of both serial and polarization resistances is similar in both modes in the initial 200 hours; Rs remained constant while $\mathrm{Rp}$ displayed a rapid increase. In the initial 200 hours, similar degradation mechanisms are therefore suggested. After this initial period, the degradation of the cells shows different Rs and Rp trends under the different operating modes. For the galvanostatic test, Rs increased for the rest of the durability test while it remained constant for the potentiostatic test. A significant increase of Rs was previously 


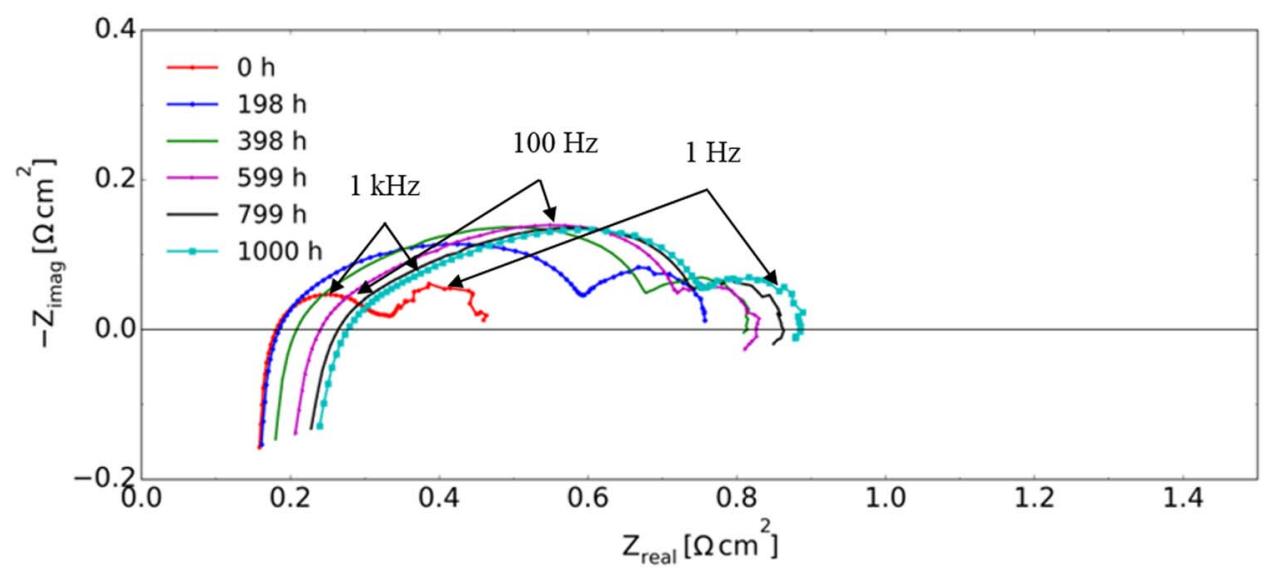

Figure 4. Evolution of impedance as function of time during the galvanostatic operation of Cell B with $65 \% \mathrm{H}_{2} \mathrm{O}+25 \% \mathrm{CO}_{2}+10 \% \mathrm{H}_{2}$ supplied to the fuel electrode compartment and $\mathrm{O}_{2}$ supplied to the oxygen electrode compartment at $750^{\circ} \mathrm{C}$, at $0.75 \mathrm{~A} / \mathrm{cm}^{2}$.

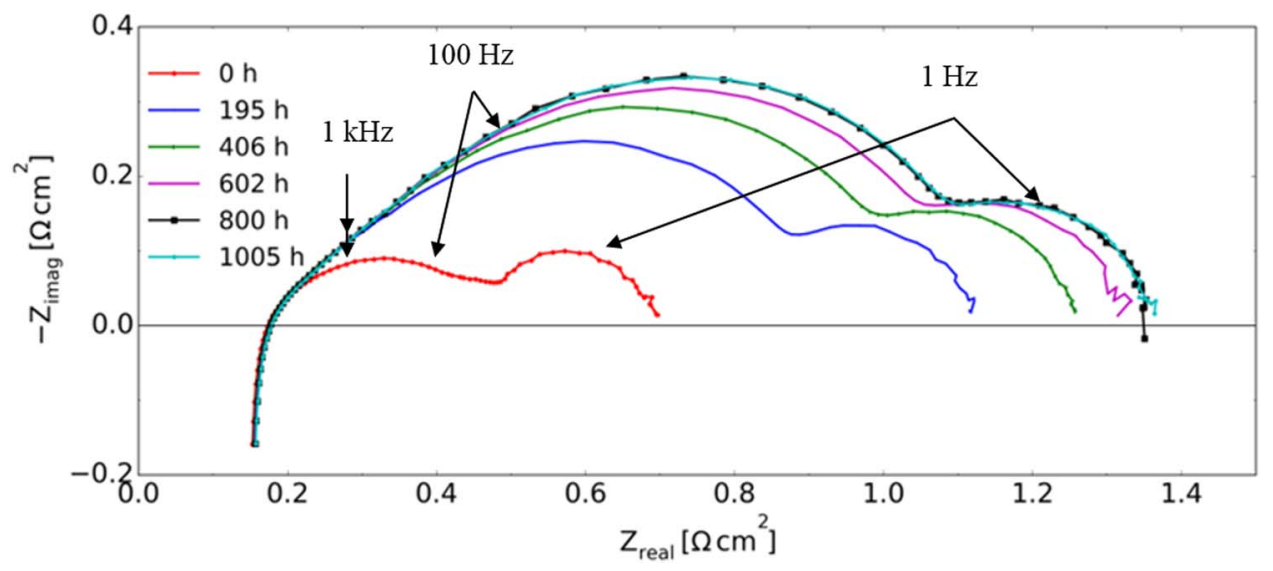

Figure 5. Evolution of impedance as function of time during the potentiostatic operation of Cell C with $65 \% \mathrm{H}_{2} \mathrm{O}+25 \% \mathrm{CO}_{2}+10 \% \mathrm{H}_{2}$ supplied to the fuel electrode compartment and $\mathrm{O}_{2}$ supplied to the oxygen electrode compartment at $750^{\circ} \mathrm{C}$, at $1.2 \mathrm{~V}$.

observed under conditions of high current densities/over potentials at the fuel electrode. ${ }^{25}$ From the results in the current study, it is suggested that running co-SOEC in potentiostatic mode seems to prevent this severe degradation mechanism from occurring because the current density is decreasing during testing below a critical value. In that way, the cell is "protected" from this specific degradation mechanism.

To analyze the change of the cell performance, $\mathrm{i}-\mathrm{V}$ curves recorded before the beginning and after the end of durability testing are compared in Figure 7 and Figure 8. For Cell B, there is a clear change of the slope of the curves before and after testing (see Figure 7), representing an increase of the cell ASR. Regarding $1.3 \mathrm{~V}$ as the reference, before testing a current density of $0.95 \mathrm{~A} / \mathrm{cm}^{2}$ was observed while after the 1000 hours of testing, the current density significantly decreased to $0.6 \mathrm{~A} / \mathrm{cm}^{2}$. However, no fuel starvation is observed in the $\mathrm{i}-\mathrm{V}$ curves, i.e. no bending of the $\mathrm{i}-\mathrm{V}$ curve at high current density over the measured range.

In Figure 8, $\mathrm{i}-\mathrm{V}$ curves before and after 1000 hours of Cell $\mathrm{C}$ under potentiostatic testing are plotted. After testing the degradation of the cell ASR is also significant. Taking $1.3 \mathrm{~V}$ as reference, at the start of the test a current density of $0.9 \mathrm{~A} / \mathrm{cm}^{2}$ was observed which decreased to $0.45 \mathrm{~A} / \mathrm{cm}^{2}$ at the end of durability testing.

To further identify the degradation mechanism pertaining to the individual electrodes, analysis of EIS spectra using distribution of relaxation times (DRT) was performed. ${ }^{26}$ To assign single electrode processes to a specific frequency or frequency range in the DRT, a gas shift analysis was done on both electrodes at OCV prior to and after the durability tests. To identify the process(es) related to the fuel electrode,

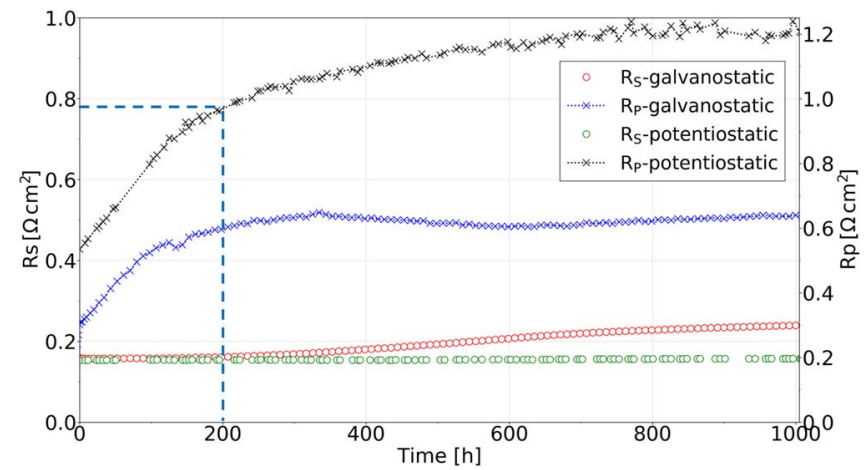

Figure 6. Variation of serial (Rs) and polarization (Rp) resistances over time for durability testing with $65 \% \mathrm{H}_{2} \mathrm{O}+25 \% \mathrm{CO}_{2}+10 \% \mathrm{H}_{2}$ supplied to the fuel electrode compartment and $\mathrm{O}_{2}$ supplied to the oxygen electrode compartment at $750^{\circ} \mathrm{C}$ in galvanostatic (red and blue curves) and potentiostatic (green and black curves) modes.

change of the steam content at the fuel electrode was performed while keeping the gas on the oxygen electrode unchanged and the DRT plots were compared. Similarly, to identify the process(es) related to the oxygen electrode a change from oxygen to air was made while the fuel electrode gas composition was kept constant. ${ }^{27}$ These plots are displayed in Figure 9. DRT analysis is performed on the EIS measured 


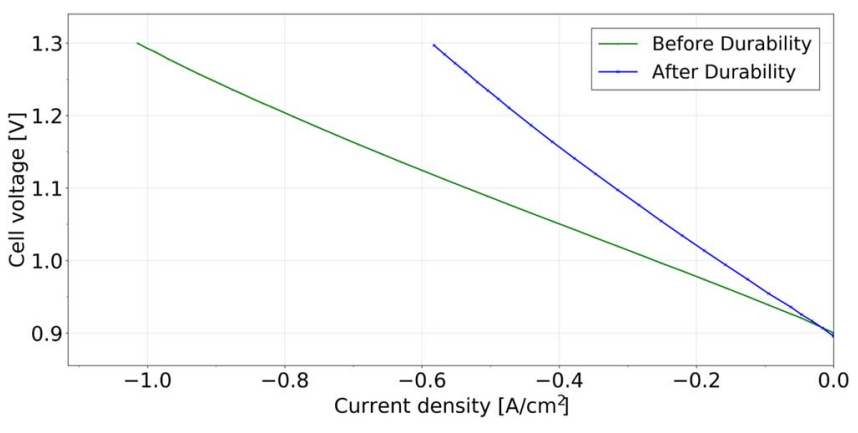

Figure 7. $\mathrm{i}-\mathrm{V}$ curves for Cell $\mathrm{B}$ before and after galvanostatic durability testing with $65 \% \mathrm{H}_{2} \mathrm{O}+25 \% \mathrm{CO}_{2}+10 \% \mathrm{H}_{2}$ supplied to the fuel electrode compartment and $\mathrm{O}_{2}$ supplied to the oxygen electrode compartment at $750^{\circ} \mathrm{C}$.

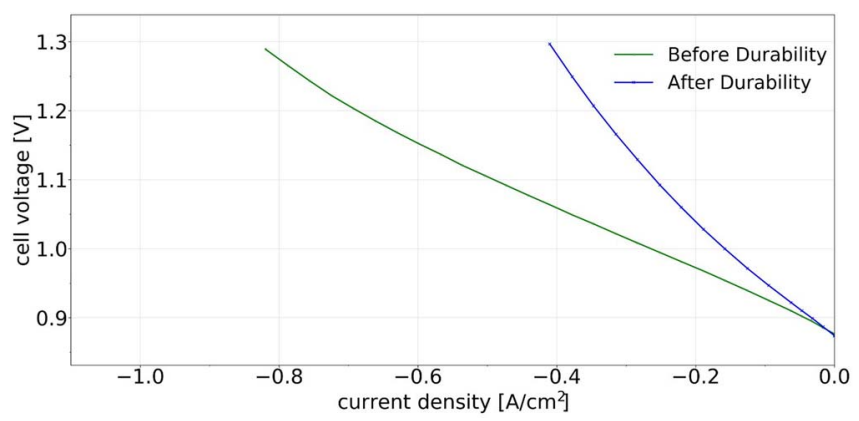

Figure 8. i-V curves for Cell $\mathrm{C}$ before and after potentiostatic durability testing with $65 \% \mathrm{H}_{2} \mathrm{O}+25 \% \mathrm{CO}_{2}+10 \% \mathrm{H}_{2}$ supplied to the fuel electrode compartment and $\mathrm{O}_{2}$ supplied to the oxygen electrode compartment at $750^{\circ} \mathrm{C}$.

on Cell $\mathrm{C}$ from the fingerprint. The behavior during initial fingerprint regarding gas shifts etc. was representative and comparable to Cell $\mathrm{A}$ and Cell B.

The relaxation times of the processes occurring at the SoA solid oxide cells are identified here including results from the literature studies performed previously. ${ }^{12,28,29}$ A complete assignment to gas conversion, diffusion, and three phase boundary (TPB) processes was performed for the particular SOEC in this work. The processes along with their relaxation frequencies are listed in Table I.

Once the electrode contribution was identified, impedance spectra were compared for both operating modes (see Figure 10) before the beginning (labelled before in Figure 10) and after the end (labelled after in Figure 10) of the durability test at OCV. Significant increase of resistances was observed indicating degradation of the cells under operation, thus confirming the results after the analysis of the $\mathrm{i}-\mathrm{V}$ curves and the current/voltage trends during operation (see above). The polarization resistances were further analyzed to identify the degradation of individual electrodes using DRT analysis.

Analyzing the polarization resistances through DRT plots in Figures 10a and 10b, both fuel and oxygen electrodes are seen to be degrading for both modes of operation. A shift in frequency of the processes was observed after long-term testing. The analysis is supported by EIS spectra analysis under current regarding the evolution of arcs. For the cell tested galvanostatically for 1000 hours, degradation is observed at the fuel electrode for both high frequency
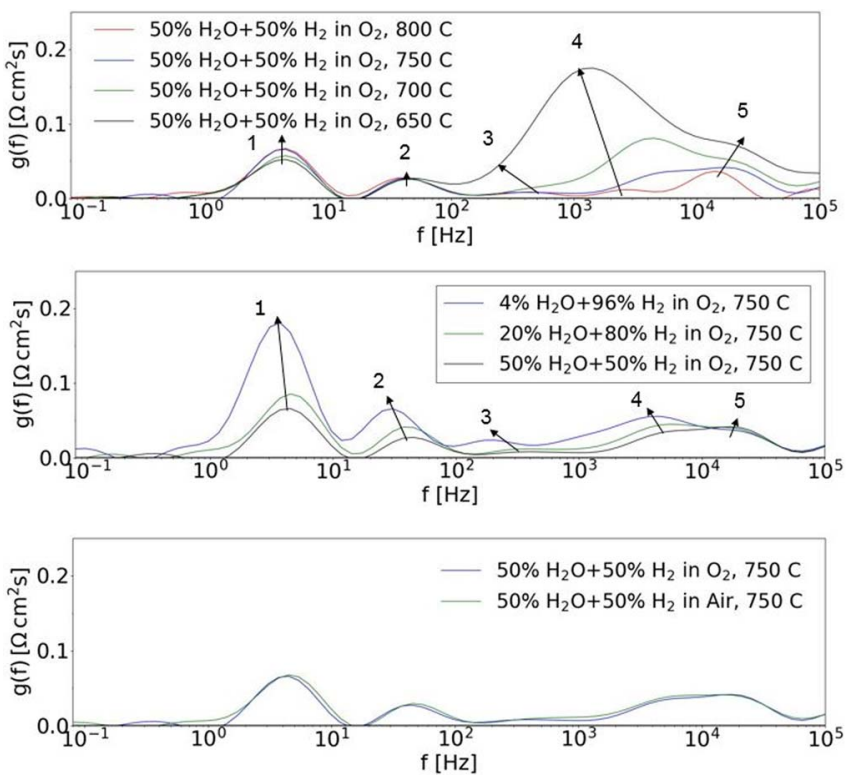

Figure 9. DRT during initial fingerprint (OCV) for Cell C (a) temperature shift (b) fuel electrode gas shift (b) oxygen electrode gas shift.

process $(1-10 \mathrm{kHz})$ and medium frequency process $(100-1000 \mathrm{~Hz})$. It is to be noted that medium frequency process has a contribution from the oxygen electrode as well. The DRT analysis shows an increase of processes for both electrodes by a factor of 3-4 (see processes 3 and 4 in Figure 10a), while the high frequency arc (see process 5 in Figure 10a) itself increased by a factor of 4, approximately as compared to the initial ASR. Previous studies have indicated the loss of percolation of Ni network to be one of the major causes for the Ni-YSZ active electrode degradation. ${ }^{13-15,30}$ This phenomenon will be investigated in the microstructural analysis. Additionally, in galvanostatic testing, an increase of Rs was also observed (see Figure 6), delamination of the layers is therefore suggested since this would affect both serial and polarization resistance..$^{15,31}$

For the case of potentiostatic testing, it is obvious that the serial resistance remained constant, while the polarization resistance increased significantly. Further, DRT of the polarization resistance points toward both fuel electrode and oxygen electrode degradation at the frequency range of 500-10000 Hz. The increase of the ASR through DRT is in the order of 2-2.5 times the initial. The process 4 in Figure 10b degraded more significantly as compared to the test at galvanostatic conditions.

For some degradation mechanisms, electrode overpotentials were discussed as major parameter. ${ }^{14}$ In this study the overpotential of the whole cell including the electrolyte was considered. The overpotential of the cells under durability testing was calculated for the tests in this study as: ${ }^{18}$

$$
O p=V-O C V
$$

where, Op is the cell overpotential, $\mathrm{V}$ is the cell voltage, OCV is the open circuit voltage.

These values are displayed in Table II.

Table I. Assignment of single electrode processes in the SOEC as a result of initial fingerprint EIS analysis using DRT. ${ }^{29}$

No. in Figure 9
Process

Gas conversion

Diffusion

Fuel and oxygen electrode

Fuel and oxygen electrode, TPB processes

Fuel electrode, oxygen ion transport
Relaxation frequency

$1-3 \mathrm{~Hz}$

30-50 Hz

100-1000 Hz

$1-8 \mathrm{kHz}$

$18-20 \mathrm{kHz}$ 

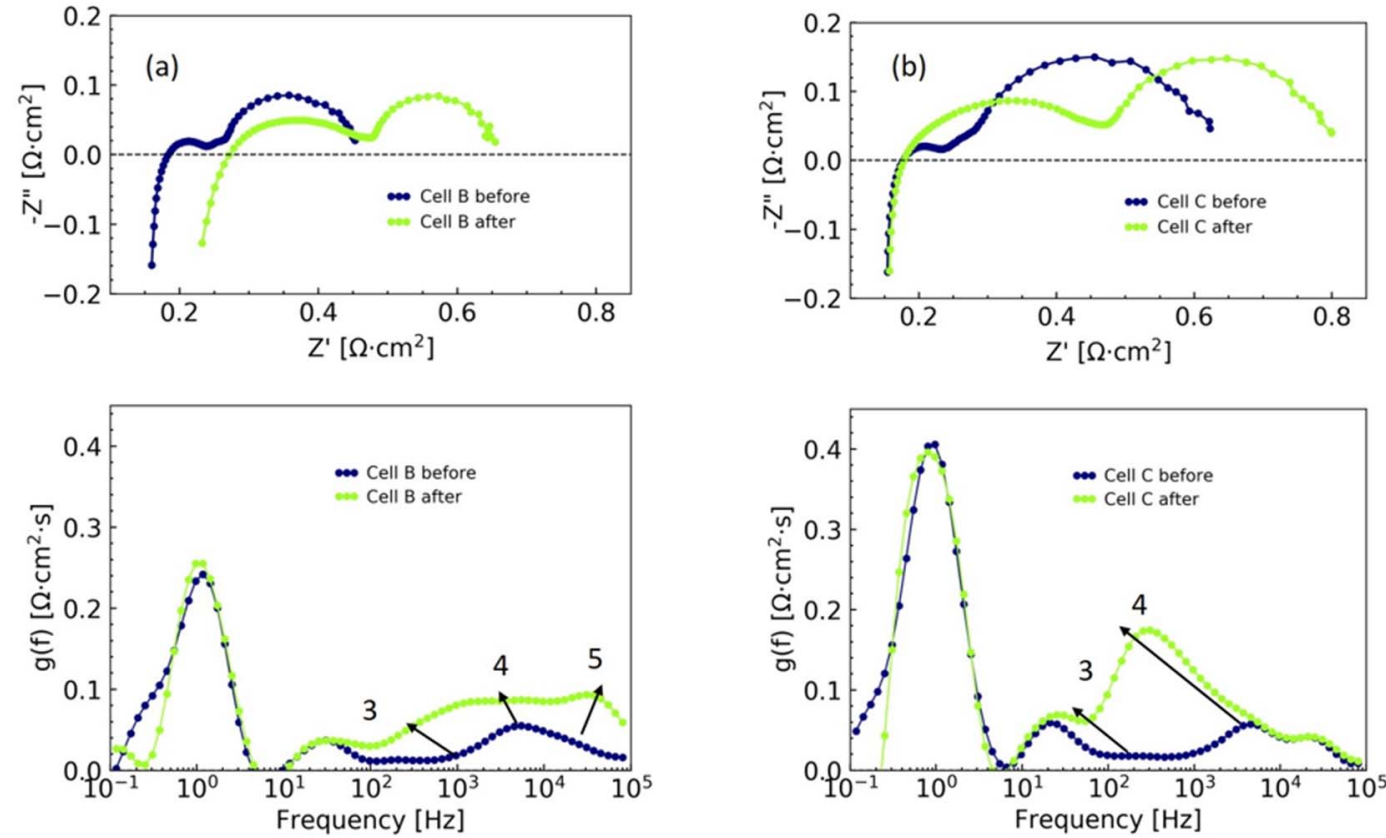

Figure 10. EIS and DRT-before and after (a) galvanostatic testing, (b) potentiostatic testing at $\mathrm{OCV}$ with $65 \% \mathrm{H}_{2} \mathrm{O}+25 \% \mathrm{CO}_{2}+10 \% \mathrm{H}_{2}$ supplied to the fuel electrode compartment and $\mathrm{O}_{2}$ supplied to the oxygen electrode compartment at $750^{\circ} \mathrm{C}$.

\section{Table II. Overpotential at the beginning and end of durability testing.}

\section{Galvanostatic}

Potentiostatic

Regardless of the difference of the current density at the beginning of the test in both modes, and thereby the ASR, the overpotential for both modes are comparable, as it was aimed at. For the galvanostatic test of Cell B, the overpotential for the cell increased by a magnitude of $250 \mathrm{mV}$. Interestingly, since the conversion arc remains constant, the overpotential can be clearly attributed to the electrode processes as displayed in Figure 10a. Both oxygen and fuel electrode contribute to the increase of overpotential. However, an extra contribution from the fuel electrode is seen at high frequency which can result from the increasing overpotential.

For the potentiostatic test of Cell $\mathrm{C}$, the start and the end of the test have similar overpotential. This is as expected since the potential of the cell is kept constant in potentiostatic mode while the current density decreases over the time, from $0.59 \mathrm{~A} / \mathrm{cm}^{2}$ to $0.32 \mathrm{~A} / \mathrm{cm}^{2}$ over the 1000 hours of testing. The attribution of electrode contributions to the degradation is more complex than in the case of galvanostatic operation since the gas conversion is different at the start and end of the test. The DRT results indicate that both electrodes are degrading as seen from Figure 10b. The difference of degradation mechanisms compared to the galvanostatic test is seen by the high frequency arc attributed to the fuel electrode which is constant throughout the potentiostatic test.

\section{Microstructural Analysis}

To complement the electrochemical results, Cells A, B, and C were analyzed with the help of a Scanning Electron Microscope (SEM). The cells were investigated at $1 \mathrm{keV}$ under In-lens detector to visualize the percolating Ni network. Pores, YSZ and non-percolating Ni are seen as dark particles in In-lens images, while percolated Ni particles appear as bright spots. Complementary Secondary electron (SE-2) images are also shown to better visualize the phases present in the samples.

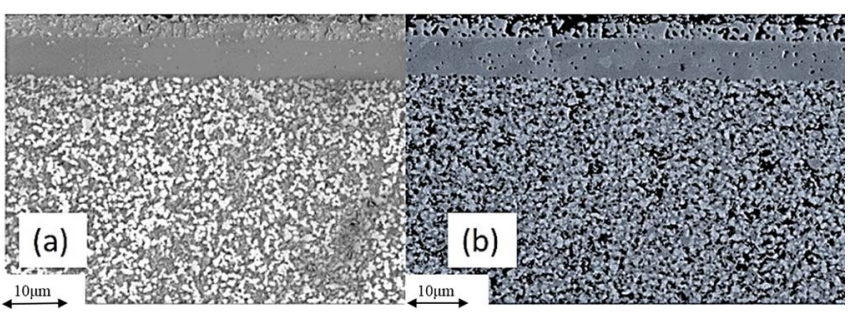

Figure 11. (a) In-lens and (b) SE-2 SEM images taken from the reference Cell A.

By comparing the Ni particles in SE-2 images to that in the In-lens, the loss of percolation can be estimated.

In all SEM figures (Figure 11, Figure 12 and Figure 13), the oxygen electrode (LSCF-CGO) is on top, followed by the CGO barrier layer, the YSZ electrolyte and the Ni-YSZ active layer and support layer for the fuel electrode at the bottom. The bright particles shown in the

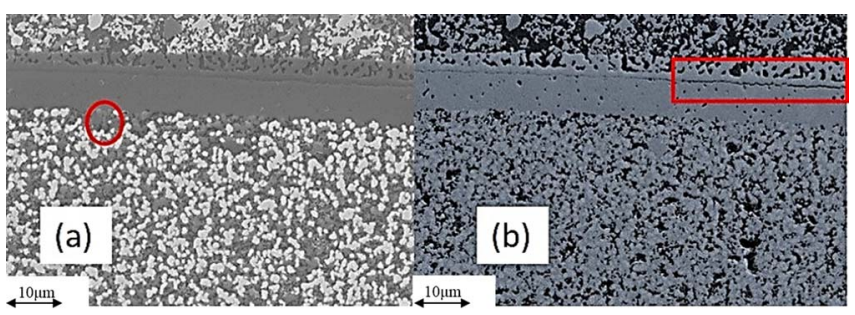

Figure 12. (a) In-lens and (b) SE-2 SEM images taken from $\mathrm{H}_{2}$ outlet of Cell $\mathrm{B}$ after galvanostatic test. 


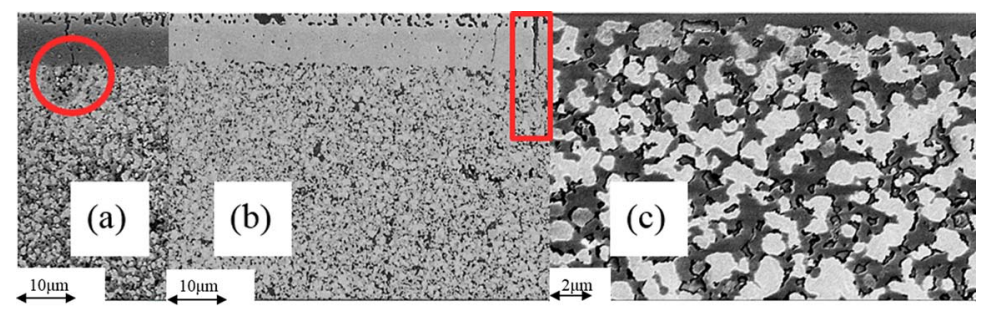

Figure 13. (a) In-lens, (b) SE-2 SEM images and (c) In-lens percolation image taken from $\mathrm{H}_{2}$ inlet of Cell $\mathrm{C}$ tested potentiostatically.

In-lens images are the percolating $\mathrm{Ni}$ particles, while the nonpercolating (isolated) Ni particles appear to be dark.

When compared with the reference cell in Figure 11, Ni seems to percolate to a lesser degree in the galvanostatically tested cell (specified with marker in Figure 12a). Fuel electrode degradation was concluded from the electrochemical analysis, which is thus confirmed by the percolation images taken from cell pieces at the gas outlet in Figure 12. A loss of active TPBs seems thus responsible for the observed degradation. ${ }^{14,24,30}$ The images are representative of the cell in general, even though only the image from the $\mathrm{H}_{2}$ outlet is shown. In addition, a gap is observed at the cell piece close to the gas outlet, at the interface of CGO and YSZ layers in the SE-2 image clearly (see marker on Figure 12b). The delamination can have occurred during test (as there was an increase of the serial resistance) or in the post test preparations on spots that were weakened during the test.

In Figure 13, images were taken at cell pieces from fuel electrode outlet of the Cell $\mathrm{C}$ where it is clearly observed that the cell is cracked from oxygen electrode, through the inter-diffusion barrier layer, the electrolyte and into the active fuel electrode (see marker on Figure 13b). The contrast in phases is not clearly visible. However, looking at the complementary In-lens image (see marker Figure 13a) it is observed that the particles in the vicinity of the crack are no longer percolating, and it is probable that locally oxidation of $\mathrm{Ni}$ has taken place. To analyze the onset of cracks, OCV values are compared at the beginning and the end of the durability test. The OCV values were similar (see Figure 8) and therefore it is probable that the crack did not occur during the durability testing.

Once the durability test was completed, the cell was characterized with varying gas compositions on both fuel and oxygen electrode as described in the Experimental section prior to cooling down the cell. During this characterization, a sudden increase of ASR was observed along with a change of the temperature at high steam content of over $80 \%$. We assume that the cracks started to appear from the active fuel electrode vertically through the cell from this point onwards. This further leads to a drop of OCV at high steam conditions and co-electrolysis when compared to the initial fingerprint. Hence, the cracks are not a consequence of the long-term test.

It was desirable to investigate the percolation of the Ni particles in other parts of the cell, where the cell was not cracked completely, and the layers were in adhesion. In Figure 13c, percolation of $\mathrm{Ni}$ particles is observed through 3 In-lens images at $1 \mathrm{keV}$. At the active fuel electrode at $20 \mathrm{kX}$ magnification, the network of particles right next to the electrolyte (see top of the image) seem to be percolating. Hence, no considerable loss is observed adjacent to the electrolyte in the active fuel electrode. As mentioned earlier, Ni percolation is representative of the whole cell i.e, similar behavior was observed in different locations of the cell from $\mathrm{H}_{2}$ inlet to outlet.

In contrast to the observations after testing in galvanostatic mode, no cracks along the YSZ/CGO interface were observed after the potentiostatic test, which is in line with the constant serial resistance over time as seen from the EIS.

\section{Conclusions}

Two SoA cells were tested for durability in galvanostatic and potentiostatic modes for a comparison of the degradation mechanisms during co-electrolysis of steam and $\mathrm{CO}_{2}$. The overall degradation behaved similarly. There was a faster initial degradation of both cells'
ASR in the initial $200 \mathrm{~h}$ followed by a period of slower degradation over the later ca. $800 \mathrm{~h}$ of operation. EIS characterization of the cells before and after test showed a degradation of both electrodes. EIS measurements during operation support this finding. A similar behavior of the polarization and the serial resistance occurred in the initial 200 hours with increase of only Rp in both modes, while Rs remained constant. This suggests similar degradation mechanisms. The degradation continued differently after this initial period. In the remaining testing hours, both Rs and Rp increased in the galvanostatic mode while only $\mathrm{Rp}$ increased in the potentiostatic mode. The reason for these different long-term degradation mechanisms can be due to the different trends of overpotential over time. While at the start of both tests the overpotentials were similar, the overpotential increased over the time in the galvanostatic mode as the current density was kept constant. On the other hand, the overpotential remained constant in the potentiostatic mode because the voltage was kept constant. Thus, overpotential related degradation mechanisms will not occur to the same extent as in galvanostatic mode. This is also evident from the increase of the high frequency arc attributed to the fuel electrode, which was only observed in the galvanostatic test. In the potentiostatic mode the cell is obviously protected by automatically lowering the current density in the course of degradation and does not reach the critical value for the threshold of such an electrochemical degradation process related to the respective electrodes. SEM analysis indicates loss of percolation of the Ni network at the active fuel electrode in the galvanostatic mode. The study has shown that operating a SoA cell in potentiostatic mode in co-electrolysis is an interesting mode to prevent some causes for degradation.

\section{Acknowledgments}

The author wishes to thank H. Henriksen, M. Davodi, Dr. J. Bentzen and Dr. K. Thyden for their technical help with measurement and testing. The research leading to these results has received funding from the European Union's Horizon 2020 framework program (H2020) for the Fuel Cells and Hydrogen Joint Technology Initiative under grant agreement no. 699892 ("Efficient Co-Electrolyser for Efficient Renewable Energy Storage-ECo").

\section{ORCID}

M. Rao (D) https://orcid.org/0000-0001-6666-9450

\section{References}

1. European Commission. Roadmap 2050. Policy, 1 (2012).

2. J. Sanz-Bermejo, J. Muñoz-Antón, J. Gonzalez-Aguilar, and M. Romero, "Part load operation of a solid oxide electrolysis system for integration with renewable energy sources." Int. J. Hydrogen Energy, 40, 8291 (2015).

3. A. B. Gallo, J. R. Simões-Moreira, H. K. M. Costa, M. M. Santos, and E. Moutinho dos Santos, "Energy storage in the energy transition context: A technology review." Renew. Sustain. Energy Rev., 65, 800 (2016).

4. E. Giglio, A. Lanzini, M. Santarelli, and P. Leone, "Synthetic natural gas via integrated high-temperature electrolysis and methanation: Part I - energy performance." J. Energy Storage, 1, 22 (2015).

5. S. D. Ebbesen, S. H. Jensen, A. Hauch, and M. B. Mogensen, "High temperature electrolysis in alkaline cells, solid proton conducting cells, and solid oxide cells." Chem. Rev, 114, 10697 (2014).

6. J. Aicart, F. Usseglio-Viretta, J. Laurencin, M. Petitjean, G Delette, and L. Dessemond, "Operating maps of high temperature $\mathrm{H}_{2} \mathrm{O}$ electrolysis and $\mathrm{H}_{2} \mathrm{O}+\mathrm{CO}_{2}$ co-electrolysis in solid oxide cells." Int. J. Hydrogen Energy, 41, 17233 (2016). 
7. S. Mesfun, D. L. Sanchez, S. Leduc, E. Wetterlund, J. Lundgren, M. Biberacher, and F. Kraxner, "Power-to-gas and power-to-liquid for managing renewable electricity intermittency in the Alpine Region." Renew. Energy, 107, 361 (2017).

8. M. Fasihi, D. Bogdanov, and C. Breyer, "Techno-Economic Assessment of Powerto-Liquids (PtL) Fuels Production and Global Trading Based on Hybrid PV-Wind Power Plants." Energy Procedia, 99, 243 (2016).

9. HELMETH. High temperature electrolysis cell (SOEC). Available at: http:// www.helmeth.eu/index.php/technologies/high-temperature-electrolysis-cell-soec. (Accessed: 5th July 2017).

10. S. H. Jensen, H. Langnickel, N. Hintzen, M. Chen, X. Sun, A. Hauch, G. Butera, and L. R. Clausen, "Pressurized reversible operation of a 30-cell solid oxide cell stack using carbonaceous gases." Proceedings of EFC2017, 415 (2017).

11. H. Timmermann, W. Sawady, R. Reimert, and E. Ivers-Tiffée, "Kinetics of (reversible) internal reforming of methane in solid oxide fuel cells under stationary and APU conditions." J. Power Sources, 195, 214 (2010).

12. P. Hjalmarsson, X. Sun, Y. L. Liu, and M. Chen, "Influence of the oxygen electrode and inter-diffusion barrier on the degradation of solid oxide electrolysis cells." $J$. Power Sources, 223, 349 (2013).

13. P. Hjalmarsson, X. Sun, Y. L. Liu, and M. Chen, "Durability of high performance Ni-yttria stabilized zirconia supported solid oxide electrolysis cells at high current density." J. Power Sources, 262, 316 (2014).

14. A. Hauch, K. Brodersen, M. Chen, and M. B. Mogensen, "Ni/YSZ electrodes structures optimized for increased electrolysis performance and durability." Solid State Ionics, 293, 27 (2016).

15. X. Sun, M. Chen, Y. L. Liu, P. Hjalmarsson, S. D. Ebbesen, S. H. Jensen, M. B. Mogensen, and P. V. Hendriksen, "Durability of Solid Oxide Electrolysis Cells for Syngas Production." J. Electrochem. Soc., 160, F1074 (2013).

16. S. D. Ebbesen, J. Høgh, K. A. Nielsen, J. U. Nielsen, and M. Mogensen, "Durable SOC stacks for production of hydrogen and synthesis gas by high temperature electrolysis." Int. J. Hydrogen Energy, 36, 7363 (2011).

17. X. Zhang, J. E. O'Brien, R. C. O'Brien, and G. K. Housley, "Durability evaluation of reversible solid oxide cells." J. Power Sources, 242, 566 (2013).

18. T. Kushi, "Effects of sulfur poisoning on degradation phenomena in oxygen electrodes of solid oxide electrolysis cells and solid oxide fuel cells." Int. J. Hydrogen Energy, 42, 9396 (2017).

19. A. Hauch and M. B. Mogensen, Advances in Medium and High Temperature Solid Oxide Fuel Cell Technology. 574, 31 (2017).
20. M. Chen, X. Sun, C. Chatzichristodoulou, S. Koch, P. V. Hendriksen, and M. B. Mogensen, "Thermoneutral Operation of Solid Oxide Electrolysis Cells in Potentiostatic Mode.” ECS Trans. 78, 3077 (2017).

21. S. H. Jensen, A. Hauch, P. V. Hendriksen, and M. Mogensen, "Advanced Test Method of Solid Oxide Cells in a Plug-Flow Setup." J. Electrochem. Soc., 156, B757 (2009).

22. S. D. Ebbesen, C. Graves, A. Hauch, S. H. Jensen, and M. Mogensen, "Poisoning of Solid Oxide Electrolysis Cells by Impurities." J. Electrochem. Soc., 157, B1419 (2010).

23. C. Ravdav Graves, (2012).

24. K. Thydén, Y. L. Liu, and J. B. Bilde-Sørensen, "Microstructural characterization of SOFC Ni-YSZ anode composites by low-voltage scanning electron microscopy." Solid State Ionics, 178, 1984 (2008).

25. R. Knibbe, M. L. Traulsen, A. Hauch, S. D. Ebbesen, and M. Mogensen, "Solid oxide electrolysis cells: Degradation at high current densities." J. Electrochem. Soc., 157, B1209 (2010)

26. S. H. Jensen, J. Hjelm, A. Hagen, and M. Mogensen, "Electrochemical impedance spectroscopy as diagnostic tool." Handb. Fuel Cells, 6, (2010).

27. S. H. Jensen, A. Hauch, P. V. Hendriksen, M. Mogensen, N. Bonanos, and T. A Jacobsen, "Method to Separate Process Contributions in Impedace Spectra by Variation of Test Conditions." J. Electrochem. Soc., 154, B1325 (2007).

28. A. Leonide, B. Rüger, A. Weber, W. A. Meulenberg, and E. Ivers-Tiffée, "Impedance Study of Alternative ( $\mathrm{La}, \mathrm{Sr}$ ) $\mathrm{FeO}_{3}-\delta$ and (La, Sr) (Co, $\mathrm{Fe}) \mathrm{O}_{3}-\delta$ MIEC Cathode Compositions." J. Electrochem. Soc., 157, B234 (2010).

29. A. Mahmood, S. Bano, J.H. Yu, and K. H. Lee, "High-performance solid oxide electrolysis cell based on ScSZ/GDC (scandia-stabilized zirconia/gadolinium-doped ceria) bi-layered electrolyte and LSCF (lanthanum strontium cobalt ferrite) oxygen electrode." Energy, 90, 344 (2015).

30. M. Chen, Y. L. Liu, J. J. Bentzen, W. Zhang, X. Sun, A. Hauch, Y. Tao, J. R. Bowen, and P. V. Hendriksen, "Microstructural Degradation of Ni/YSZ Electrodes in Solid Oxide Electrolysis Cells under High Current." J. Electrochem. Soc., 160, F883 (2013).

31. R. R. Mosbæk, J. Hjelm, R. Barfod, J. Høgh, and P. V. Hendriksen, "Electrochemical characterization and degradation analysis of large SOFC stacks by impedance spectroscopy." Fuel Cells, 13, 605 (2013). 